\title{
CHARACTERIZATION OF ALKALINE XYLANASES FROM BACILLUS PUMILUS
}

\author{
Marta Cristina Teixeira Duarte $^{1^{*}}$; Ana Carolina Alcazar Pellegrino ${ }^{1}$; Edilberto Princi Portugal ${ }^{1}$; Alexandre \\ Nunes Ponezi'; Telma Teixeira Franco ${ }^{2}$
}

${ }^{1}$ Centro Pluridisciplinar de Pesquisas Químicas, Biológicas e Agrícolas, CPQBA, UNICAMP, Campinas, SP, Brasil; ${ }^{2}$ Faculdade de Engenharia Química, FEQ, UNICAMP, Campinas, SP, Brasil

Submitted: December 27, 1999; Returned to authors for corrections: April 07, 2000; Approved: June 26, 2000

\begin{abstract}
Alkaline xylanases produced by four different strains of Bacillus pumilus were characterized. The optimal $\mathrm{pH}$ and temperature were $\mathrm{pH} 9.0$ and $60^{\circ} \mathrm{C}$ for strain $13_{\mathrm{a}}$, and $\mathrm{pH} 8.0$ and $55^{\circ} \mathrm{C}$ for strains $5_{2}, 5_{14}$, and $4_{\mathrm{a}}$. Under these conditions the following activities were found after $10 \mathrm{~min}$ in the presence of $1 \%$ xylan (birchwood): $328 \mathrm{U} \cdot \mathrm{ml}^{-1}, 131 \mathrm{U} \cdot \mathrm{ml}^{-1}, 90 \mathrm{U} \cdot \mathrm{ml}^{-1}$, and $167{\mathrm{U} \cdot \mathrm{ml}^{-1}}^{-1}$, respectively, for the four strains. The enzymes were stable at $40^{\circ} \mathrm{C}$, with $40 \%$ of the xylanase activity remaining after 2 hours for the enzymes of strain $5_{2}$ and $60 \%$ for the other three strains. Stability at $50^{\circ} \mathrm{C}$ was improved by addition of glycerol. Taking into account the conditions under which kraft pulps are bleached during the manufacture of paper, xylanases from B. pumilus exhibit favorable potential for application to bleaching in the paper making process.
\end{abstract}

Key words: xylan, xylanase, $B$. pumilus, kraft pulp bleaching

\section{INTRODUCTION}

Bleaching in the kraft papermaking process consists in decolorizing and removing the highly colored residual lignin from washed pulp. Most present bleaching sequences are based on elemental chlorine $\left(\mathrm{Cl}_{2}\right)$, chlorine dioxide, and alkaline extraction of the pulp (19). Viikari et al. (21) reported on the ability of xylanase to facilitate subsequent chemical bleaching of kraft pulps, known as xylanase prebleaching. This results in a lower chlorine dosage, a lower chemical cost, and lower chloroorganic concentrations in pulp and effluent. This discovery led to extensive further studies $(20,22)$.

Although many bacteria and fungi have been studied for xylanase production $(1,3,14,18)$, several xylanases commercially available are active at a neutral or acidic $\mathrm{pH}$ and their optimum temperature for activity is below $45^{\circ} \mathrm{C}$. Enzymes which are active under alkaline conditions have great potential for industrial applications as a bleaching process without any need for changes in $\mathrm{pH}$ or temperature (18).

In previous investigations $(4,7,8,9)$ we had isolated four microorganisms, identified as different strains of B. pumilus, which were able to produce xylanase under alkaline conditions (8). The bacteria are aerobic, Gram-positive, catalase-positive and oxidase-negative, and rod-shaped. Although the strains were identified as B. pumilus using the criteria in Bergey's Manual of Systematic Bacteriology, differences were observed in morphology and in some tests that don't have an effect on the final results, but which indicate that they belong to different strains. All microorganisms are capable of growing at $40^{\circ} \mathrm{C}$; however, the 13 a strain grows at $55^{\circ} \mathrm{C}$. Enzyme production was observed at $\mathrm{pH} 8.0$ to 11.0 , but higher levels were observed at $\mathrm{pH}$ 10.0, which are appropriate conditions for the bleaching process. In this report, the characterization of xylanases produced by $B$. pumilus is described. The enzymatic assays were performed at $\mathrm{pH}$ and temperature ranges close to those at which kraft pulps are bleached.

\section{MATERIALS AND METHODS}

\section{Microorganism.}

B. pumilus strains $5_{2}, 5_{14}, 13_{\mathrm{a}}$, and $4_{\mathrm{a}}$ were isolated from wood decomposition material and were maintained in a

\footnotetext{
* Corresponding author. Mailing address: Centro Pluridisciplinar de Pesquisas Químicas, Biológicas e Agrícolas, CPQBA, UNICAMP, Caixa Postal 6171, CEP 13083-970, Campinas, SP, Brasil.
} 
previously described media (12) containing xylan as the carbon source, which contained (g/L): birchwood xylan (Sigma), 10.0; peptone, 1.0; Tween 80, 1.0; $\left(\mathrm{NH}_{4}\right)_{2} \mathrm{SO}_{4}, 1.4 ; \mathrm{KH}_{2} \mathrm{PO}_{4}, 2.0$; urea, $0.3 ; \mathrm{CaCl}_{2}, 0.3 ; \mathrm{MgSO}_{4} .7 \mathrm{H}_{2} \mathrm{O}, 0.3$; agar-agar, 20.0 ; and solutions of the following salts (mg/L): $\mathrm{FeSO}_{4} \cdot 7 \mathrm{H}_{2} \mathrm{O}, 5.0 ; \mathrm{MnSO}_{4} \cdot \mathrm{H}_{2} \mathrm{O}$, 1.6; $\mathrm{ZnSO}_{4} .7 \mathrm{H}_{2} \mathrm{O}, 1.4$; and $\mathrm{CoCL}_{2}, 2.0$. The $\mathrm{pH}$ was adjusted to 10.0 with $2 \mathrm{~N} \mathrm{NaOH}$. The cultures were grown at $45^{\circ} \mathrm{C}$ for 48 hours.

Inoculum preparation. The cultures were transferred to 250 $\mathrm{ml}$ Erlenmeyer flasks, containing $50 \mathrm{ml}$ of the liquid media described above, and incubated at $45^{\circ} \mathrm{C}$ in a rotary shaker $(250$ rpm) during 20 hours. Cell concentrations of the different cultures were adjusted to $3 \% \mathrm{~T}$ (transmittance) in relation to distilled water at $600 \mathrm{~nm}$.

\section{Enzyme production.}

The initial number of cells for fermentation was equivalent to $10^{8} \cdot \mathrm{ml}^{-1}$. For xylanase production, the bacteria were grown in the media described, with optimized xylan and peptone concentrations for each strain as shown in Table 1. These concentrations were determined by means of response surface methods in a previous study (7). Fermentation was carried out in shake flasks under the same inoculum conditions $\left(20 \mathrm{~h}, 45^{\circ} \mathrm{C}\right.$, and $250 \mathrm{rpm}$ ). The fermented media was centrifuged for $15 \mathrm{~min}$ at $12000 \mathrm{x} \mathrm{g}$ to the assay activity.

\section{Enzyme activity assay.}

Xylanase (1,4- $\beta$-D-xylan xylanohydrolase, EC 3.2.1.8. xyl) activity was assayed using birchwood xylan $1 \%$ solution as the substrate, as described by Bailey et al. (2), and the amount of reducing sugars released was determined by the dinitrosalicylic acid method (13).

Filter paper cellulase (FPase) activity was assayed as an indicator of overall cellulolytic activity and determined according to IUPAC recommendations (10), using Wathman No. 1 filter paper $(50 \mathrm{mg}$ ) as a substrate in $100 \mathrm{mM}$ glycine- $\mathrm{NaOH}$ buffer, $\mathrm{pH} 10.0$.

One unit of enzyme activity was defined as $1 \mu \mathrm{mol}$ of xylose or glucose equivalents produced per minute under the given conditions.

\section{Birch xylan solution.}

A $1 \mathrm{~g}$ sample of birch xylan in $80 \mathrm{ml}$ of $100 \mathrm{mM}$ buffer, as indicated subsequently, was heated to boiling, cooled by stirring, diluted to $100 \mathrm{ml}$ with buffer and kept at $-20^{\circ} \mathrm{C}$

Effect of $\mathrm{pH}$ and temperature on xylanase activity.

The effect of $\mathrm{pH}$ on xylanase activity was studied in the following buffers $(100 \mathrm{mM})$ : sodium phosphate, $\mathrm{pH}$ 8.0; glycine$\mathrm{NaOH}, \mathrm{pH} 9.0$ and $\mathrm{pH}$ 10.0; and carbonate-bicarbonate, $\mathrm{pH}$ 11.0. The reaction mixture containing $0.9 \mathrm{ml}$ of xylan solution and $0.1 \mathrm{ml}$ of the crude enzyme preparations was incubated at $35-55^{\circ} \mathrm{C}$ or until activity declined, and enzyme activity was determined for different times.

Effect of temperature and pH on xylanase stability.

The remaining xylanase activity was determined after preincubation of the crude enzyme preparations at $30-60^{\circ} \mathrm{C}$ in buffers of optimal activity, without substrate, for 1, 2, 4 and $6 \mathrm{~h}$. The effect of $\mathrm{pH}$ on xylanase stability was measured over the $\mathrm{pH}$ range of 8.0 to 11.0 at a defined optimal temperature. After incubation, residual activity was determined under optimal assay conditions for each strain.

\section{Protein measurement.}

Protein concentration was measured by the method of Sedmak and Grossberg (16). Bovin serum albumin was used as a standard. The results were used to calculate specific activity.

\section{Kinetic determinations.}

$\mathrm{K}_{\mathrm{m}}$ and $\mathrm{V}_{\text {máx. }}$ values were determined from Lineweaver-Burk plots (11), using xylan concentrations varying from 0.5 to $3.0 \%$ $(\mathrm{w} / \mathrm{v})$.

\section{RESULTS AND DISCUSSION}

\section{Previous results}

Throughout preliminary studies were used the original Mandels and Stenberg medium(12) that contains 1\% xylan. In order to determine the ideal concentrations of xylan and peptone for maximum xylanase production, was used response surface analysis (7). The optimization study was relevant because with this medium, the levels of enzymes could be increased as compared to a conventional medium. Moreover, the strains showed different requirements for xylan or peptone, as shown in Table 1.

Table 1. Ideal concentration of xylan and peptone in the fermentation media, and xylanase activity for different strains of $B$. pumilus obtained from wood material decomposition. (Tests carried out at $45^{\circ} \mathrm{C}$ and $\mathrm{pH} 10$ ).

\begin{tabular}{ccccc}
\hline \multirow{2}{*}{$\begin{array}{c}\text { B. pumilus } \\
\text { strains }\end{array}$} & $\begin{array}{c}\text { Optimized Medium } \\
\text { xylan } \\
(\mathrm{g} / \mathrm{l})\end{array}$ & $\begin{array}{c}\text { Peptone } \\
(\mathrm{g} / \mathrm{l})\end{array}$ & $\begin{array}{c}\text { xylanase activity } \\
\left(\mathrm{U}_{\mathrm{m}} \mathrm{ml}^{-1}\right)\end{array}$ & $\begin{array}{c}\text { Original Medium* } \\
\text { xylanase activity } \\
\left(\mathrm{U} \cdot \mathrm{ml}^{-1}\right)\end{array}$ \\
\hline $5_{2}$ & 30.0 & 6.0 & 33 & 3 \\
$5_{14}$ & 58.3 & 6.0 & 9 & 2.5 \\
$13_{\mathrm{a}}$ & 10.0 & 10.0 & 23 & 1.5 \\
$4_{\mathrm{a}}$ & 50.0 & 10.0 & 25 & 4 \\
\hline
\end{tabular}

$*$ xylan $=10 \mathrm{~g} / \mathrm{l} ;$ peptone $=1.0 \mathrm{~g} / 1$

Was also defined that the time for enzyme production must be around 16h, corresponding to log phase half. After $20 \mathrm{~h}$, the cells start fast sporulation, resulting in cellular lysis. When cellular lysis occurs, proteases are liberated in to the medium with subsequent enzyme hydrolysis.

Finally, in our previous studies the molecular weight of the main protein bands of crude enzyme preparation was estimated to be about 78,900,63,800, 24,500 and 15,500 Da (9).

\section{Cellulase production from B. pumilus strains}

Fpase activity was assayed as an indicator of overall 
cellulolytic activity in crude enzyme preparations, obtained from cultivations at $\mathrm{pH} 10.0$ and $45^{\circ} \mathrm{C}$. The cellulolytic activity found was lower than $0.01 \mathrm{UPF} / \mathrm{ml}$ for all strains.

Xylanase solutions for industrial uses must be cellulase-free. Contaminating cellulase in commercial xylanase preparations can result in a loss of fiber strength (15). When cellulase activity is very low, culture filtrate can be used for treating pulp without further purification (23). Our results indicate that enzymes produced by $B$. pumilus strains meet this requirements.

\section{Enzyme characteristics. Effects of temperature and $\mathrm{pH}$ on activity and stability}

Crude xylanases from B. pumilus strains were tested for the effect of $\mathrm{pH}$ and temperature on activity. Initially, activity was determined after incubation for 5, 10, and $20 \mathrm{~min}$. Data obtained after $10 \mathrm{~min}$ are shown in Table 2 . Maximum xylanase activity was found after $10 \mathrm{~min}$ at $\mathrm{pH} 9.0$ and $60^{\circ} \mathrm{C}$ for strain $13_{\mathrm{a}}(328$ U.ml $\left.{ }^{-1}\right)$, and $\mathrm{pH} 8.0$ and $55^{\circ} \mathrm{C}$ for strains $5_{2}, 5_{14}$ and $4_{\mathrm{a}}^{\mathrm{a}}(131$ U.ml- ${ }^{-1}, 90 \mathrm{U}^{-\mathrm{ml}^{-1}}$ and $167 \mathrm{U} \cdot \mathrm{ml}^{-1}$, respectively). At $\mathrm{pH}$ 10.0, which was used during initial assays, enzymatic activities were very low and showed little variation in the temperature range studied. At pH 11.0, xylanase activity decreased rapidly, reaching insignificant levels.

Several reports have revealed that the optimum $\mathrm{pH}$ for the activity of xylanolytic enzymes produced by other bacterias does not usually exceed $\mathrm{pH} 7.0$, as in the case of enzymes from

Table 2. Effects of temperature and $\mathrm{pH}$ on the xylanolytic activity of $B$. pumilus strains after $10 \mathrm{~min}$ of incubation.

\begin{tabular}{|c|c|c|c|c|c|c|c|c|}
\hline \multirow{2}{*}{$\mathrm{pH}$} & \multirow{2}{*}{ strain } & \multicolumn{7}{|c|}{ Enzyme Activity $\left(\mathrm{U}^{\prime} \mathrm{ml}^{-1}\right)$} \\
\hline & & $35^{\circ} \mathrm{C}$ & $40^{\circ} \mathrm{C}$ & $45^{\circ} \mathrm{C}$ & $50^{\circ} \mathrm{C}$ & $55^{\circ} \mathrm{C}$ & $60^{\circ} \mathrm{C}$ & $65^{\circ} \mathrm{C}$ \\
\hline \multirow{4}{*}{8} & $5_{2}$ & 47 & 66 & 86 & 118 & 131 & & \\
\hline & $5_{14}$ & 37 & 48 & 62 & 80 & 90 & & \\
\hline & 13 & 144 & 181 & 189 & 220 & 241 & & \\
\hline & $4_{a}^{a}$ & 80 & 102 & 123 & 145 & 167 & 156 & \\
\hline \multirow{4}{*}{9} & $5_{2}$ & 42 & 63 & 79 & 100 & 95 & 108 & \\
\hline & $5_{14}^{2}$ & 28 & 37 & 50 & 58 & 66 & 79 & \\
\hline & $13_{\mathrm{a}}$ & 135 & 157 & 211 & 279 & 325 & 328 & 351 \\
\hline & $4_{a}^{a}$ & 57 & 79 & 95 & 100 & 108 & & \\
\hline \multirow{4}{*}{10} & $5_{2}$ & 9 & 13 & 15 & 15 & 10 & & \\
\hline & $5_{14}$ & 27 & 17 & 22 & 18 & 16 & & \\
\hline & $13 \mathrm{a}$ & 42 & 56 & 66 & 92 & 52 & & \\
\hline & $4_{a}^{a}$ & 22 & 33 & 50 & 41 & 30 & & \\
\hline \multirow{4}{*}{11} & $5_{2}$ & 1 & 1 & 1 & 0.1 & 0.1 & & \\
\hline & $5_{14}$ & 3 & 4 & 3 & 3 & 3 & & \\
\hline & $13_{\mathrm{a}}$ & 3 & 1 & 0.4 & 1 & 0.4 & & \\
\hline & $4_{\mathrm{a}}$ & 3 & 3 & 1 & 3 & 3 & & \\
\hline
\end{tabular}

Bacillus sp BP-23 (5), Bacillus sp (23) and Thermoanabacterium sp (17). In these cases, maximum enzymatic activity was observed, at $\mathrm{pH} 5.5$ to $7.5, \mathrm{pH} 7.0, \mathrm{pH}$ 6.0 to 7.5 , and $\mathrm{pH} 5.4$, respectively. These bacteria were able to produce active enzymes at temperatures between $45^{\circ} \mathrm{C}$ and $60^{\circ} \mathrm{C}$, and only $T$. maritima produces xylanases which are highly thermostable at $95^{\circ} \mathrm{C}$. Comparable enzymatic levels obtained in this study for B. pumilus $5_{2}(482 \mathrm{U} / \mathrm{ml})$ and $4_{a}(393 \mathrm{U} / \mathrm{ml})$ were observed for $T$. maritima $(585 \mathrm{U} / \mathrm{ml})$ and Thermoanabacterium sp $(393 \mathrm{U} / \mathrm{ml})$. However, the optimum $\mathrm{pH}$ range for xylanase activity of $B$. pumilus was higher $(\mathrm{pH} 8.0$ to $\mathrm{pH} 9.0$ ). The latter are more suitable for application of enzymes at different stages of the bleaching process without the need for changes in $\mathrm{pH}$.

After the enzymes were preincubated at several temperatures and $\mathrm{pHs}$ during different periods of time, the xylanase activity tests were carried out under the optimal conditions determined for each $B$. pumilus strain. According to results, the enzymes were reasonably stable at $40^{\circ} \mathrm{C}$. The enzymes from $B$. pumilus 5 retained around $40 \%$ of their original activity after $2 \mathrm{~h}$, while $60 \%$ was retained by the other strains (Fig. 1a). However, activity decreased gradually over time, with $30 \%$ of the activity remaining for strain $5_{2}, 50 \%$ for strain $5_{14}$ and $40 \%$ for strains $13_{\mathrm{a}}$ and $4_{\mathrm{a}}$ after $6 \mathrm{~h}$ (results not shown).

At $50^{\circ} \mathrm{C}$ and $60^{\circ} \mathrm{C}$ the enzymes were denaturated very rapidly, which is not appropriate for industrial purposes. However, according to literature, this problem is solved by an addition of a $50 \% \mathrm{w} / \mathrm{w}$ glycerol solution (1). Our results confirmed this statement since the stability of the xylanases from B. pumilus strains $5_{2}, 13_{\mathrm{a}}$ and $4_{\mathrm{a}}$ could be improved by glycerol, and there were increases from $8 \%$ to $56 \%$, from $15 \%$ to $36 \%$ and from $25 \%$ to $66 \%$, respectively, after $2 \mathrm{~h}$ at $50^{\circ} \mathrm{C}$ for these strains (Fig. 2). On the other hand, this protective effect of glycerol was not observed in enzymes from B. pumilus $5_{14}$.

The results obtained after incubation of the enzymes at different $\mathrm{pH}$ values did not show variations in xylanase activity after $2 \mathrm{~h}$ at $\mathrm{pH} 8.0$ and $\mathrm{pH} 9.0$ for enzymes of the several strains (Fig. 1b). However, at $\mathrm{pH} 10.0$ the activity decreased rapidly and inactivation was observed at $\mathrm{pH}$ 11.0.

\section{Kinetic determinations}

Kinetic parameters of the four B. pumilus xylanases in birchwood xylan are summarized in Table 3 . The crude enzymes produced from different bacterial strains showed quite different $\mathrm{K}_{\mathrm{m}}$ and $\mathrm{V}_{\text {max }}$ values for the same substrate under the conditions studied. Substrate concentration is one of most important factors which determine the velocity of enzyme reactions. The xylanases from $B$. pumilus $5_{2}$ and $5_{14}$ required lower substrate concentration to reach the $\mathrm{V}_{\max }$ for catalysis, whereas the strains $13_{\mathrm{a}}$ and $4_{\mathrm{a}}$ required higher substrate concentration (Table 3). Therefore, considering the $\mathrm{V}_{\max }$ attained by the enzymes, the xylanases from B. pumilus $13_{\mathrm{a}}$ and $4_{\mathrm{a}}$ show a higher catalytic power, and consequentetly could show a higher technology efficience. 


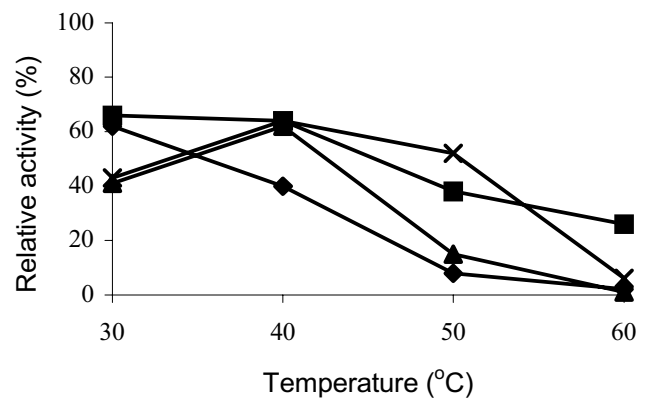

(a)

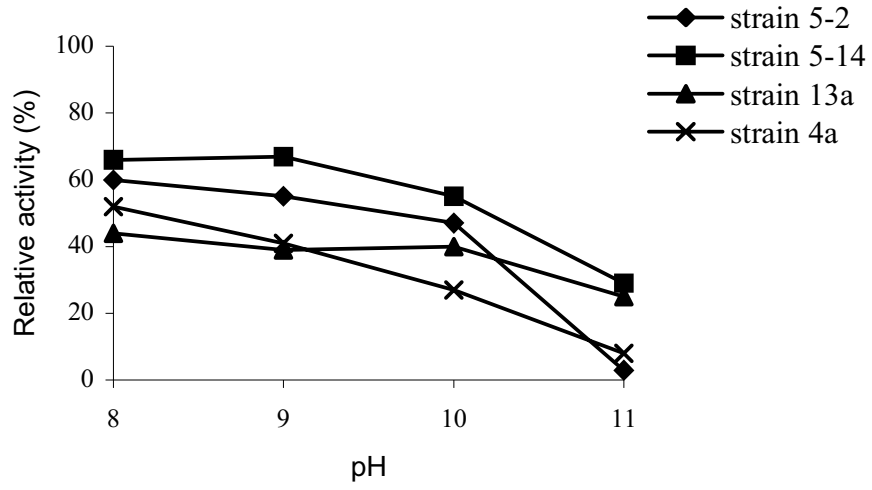

(b)

Figure 1. Xylanase activity remaining after incubation for $2 \mathrm{~h}$ at different temperatures (a), and after $2 \mathrm{~h}$ at different $\mathrm{pH}$ values (b).

strain $5_{2}($ pH 9)

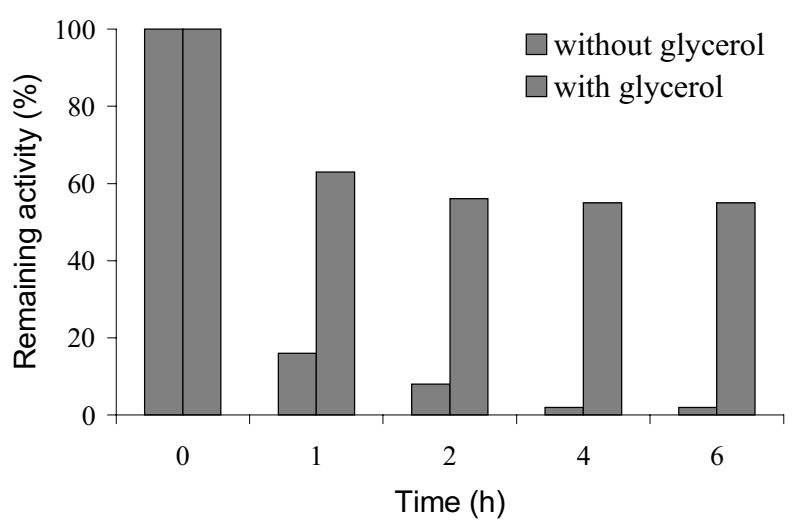

strain 13a (pH 9)

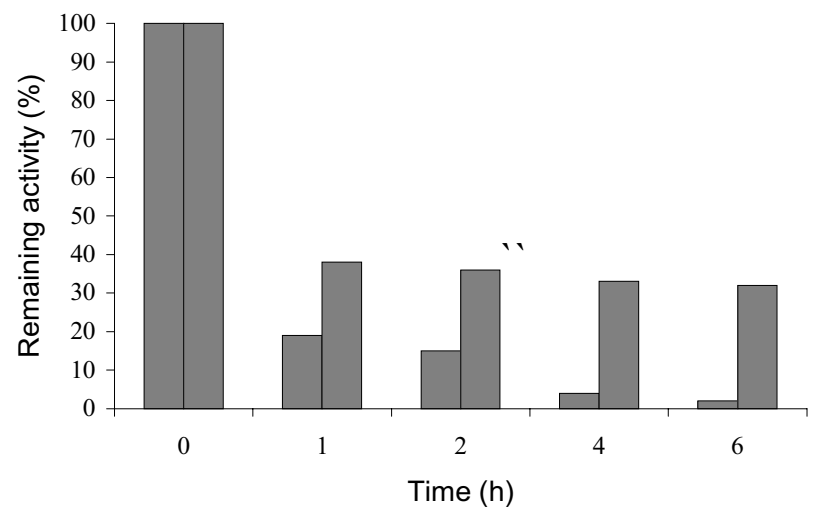

strain $5_{14}$ (pH 9)

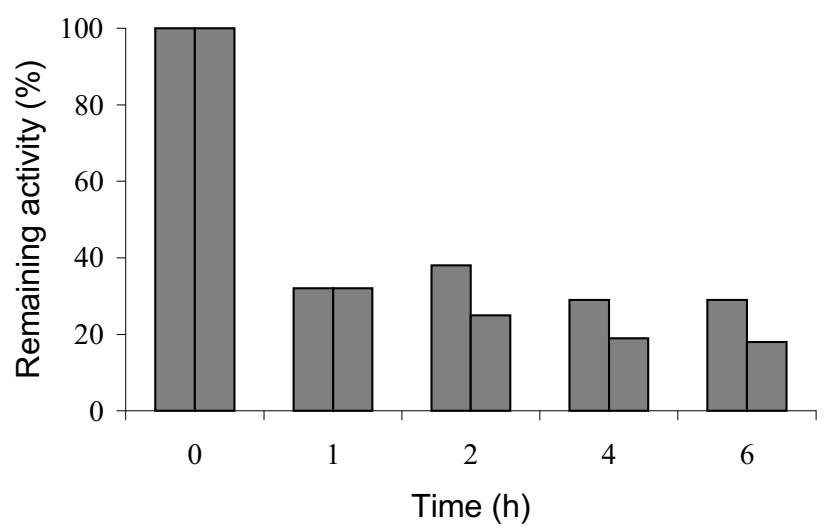

strain 4a (pH 8)

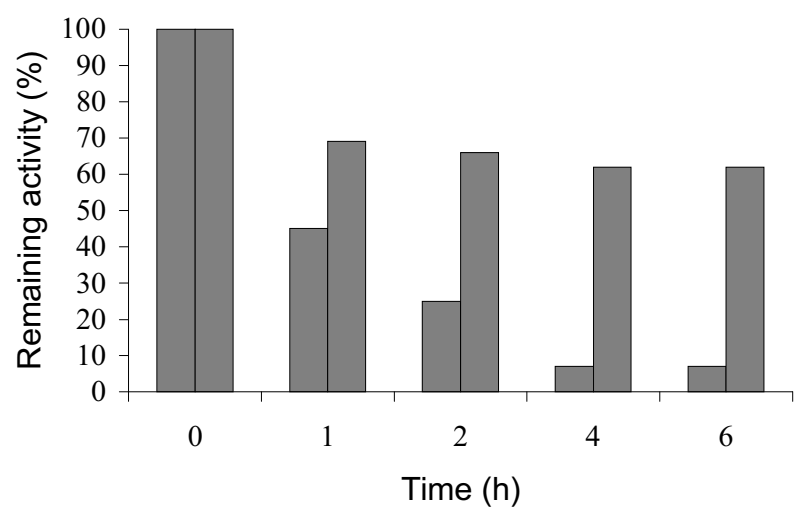

Figure 2. Effect of $50 \%$ glycerol on xylanase stability at $50^{\circ} \mathrm{C}$ on birch xylan of enzymes from different B. pumilus strains. 
Table 3. Kinetic parameters of B. pumilus xylanases in birchwood xylan.

\begin{tabular}{ccccc}
\hline $\begin{array}{c}\text { B. pumilus } \\
\text { strains }\end{array}$ & $\mathrm{pH}$ & $\begin{array}{c}\text { Temperature } \\
\left({ }^{\circ} \mathrm{C}\right)\end{array}$ & $\begin{array}{c}\mathrm{K}_{\mathrm{m}} \\
(\mathrm{mg} / \mathrm{ml})\end{array}$ & $\begin{array}{c}\mathrm{V}_{\text {máx }} \\
(\mu \mathrm{mol} / \mathrm{ml} / \mathrm{min})\end{array}$ \\
\hline $5_{2}$ & 9.0 & 55 & 8.9 & 178.57 \\
$5_{14}$ & 9.0 & 55 & 1.1 & 112.36 \\
$13_{\mathrm{a}}$ & 9.0 & 60 & 33.3 & 1666.67 \\
$4_{\mathrm{a}}$ & 8.0 & 60 & 71.4 & 1428.57 \\
\hline
\end{tabular}

\section{CONCLUSIONS}

The conditions used in our study on the activity and stability of xylanases from B. pumilus strains were based on the temperature, $\mathrm{pH}$ and time used in the kraft pulp bleaching. Taking into account industrial conditions such as dosage between 2 and 5 units $(\mathrm{U})$ per gram of dry pulp, alkaline $\mathrm{pH}$, temperature around $50^{\circ} \mathrm{C}$ and $2 \mathrm{~h}$ for reaction (6), the enzymes from B. pumilus exhibit favorable potential for application to the bleaching of kraft pulps.

\section{ACKNOWLEDGEMENTS}

This work was supported by FAPESP (Brazil). We wish to thank the André Tosello Tropical Foundation - Campinas, SP, Brazil for identification of the strains.

\section{RESUMO}

\section{Caracterização de xilanases alcalinas de Bacillus pumilus}

Xilanases alcalinas produzidas por quatro diferentes linhagens de Bacillus pumilus foram caracterizadas. $\mathrm{O} \mathrm{pH}$ e temperatura ótimos para máxima atividade enzimática foram $\mathrm{pH} 9.0$ e $60^{\circ} \mathrm{C}$ para o isolado $13_{\mathrm{a}}$, e $\mathrm{pH} 8.0$ e $55^{\circ} \mathrm{C}$ para os isolados $5_{2}, 5_{14}$ e $4_{\mathrm{a}}$. Nessas condições, as seguintes atividades foram encontradas após $10 \mathrm{~min}$ na presença de $1 \%$ de xilana (bétula): $328 \mathrm{U} \cdot \mathrm{ml}^{-1}, 131 \mathrm{U} \cdot \mathrm{ml}^{-1}, 90 \mathrm{U} \cdot \mathrm{ml}^{-1}$ e $167 \mathrm{U} \cdot \mathrm{ml}^{-1}$, respectivamente, para os quatro isolados. As enzimas foram estáveis à $40^{\circ} \mathrm{C}$, com $40 \%$ de atividade remanescente de xilanase após 2 horas para as enzimas do isolado $5_{2}$ e $60 \%$ para os outros três isolados. Estabilidade a $50^{\circ} \mathrm{C}$ foi melhorada com a adição de glicerol. Considerando-se as condições em que as polpas kraft são branqueadas durante a fabricação de papel, as xilanases de B. pumilus mostraram potencial favorável para aplicação no branqueamento no processo de fabricação de papel.

Palavras-chave: xilana, xilanase, B. pumilus, polpas kraft branqueadas

\section{REFERENCES}

1. Angelo, R.; Aguirre, C.; Curotto, E.; Esposito, E.; Fontana, J. D.; Baron, M.; Milagres, A. M. F.; Durán, N. - Stability and chemical modification of xylanase from Aspergillus sp (2MI strain). Biotechnol. Appl. Biochem. 25: 19-27, 1997

2. Bailey, M. J.; Biely, P.; Poutanen, K. - Interlaboratory testing of methods for assay of xylanase activity. J. of Biotechnology. 23: 257-270, 1992.

3. Bailey, M. J.; Buchert, J.; Viikari, L. - Effect of $\mathrm{pH}$ on production of xylanase by Trichoderma reesei on xylan and cellulose-based medium. App. Microbiol. Biotechnol. 40: 224-229, 1993.

4. Bim, M. A.; Tagliari, C. V.; Duarte, M. C. T.; Portugal, E. P.; Ponezi, A. N.; Franco, T. T. - Optimization and extraction of an alkaline xylanase produced of Bacillus pumilus. Proc. Fifth Europ. Work. on Lignocel. and Pulp, Portugal, 1998, p. 27-31.

5. Blanco, A.; Vidal, T.; Colom, J. F.; Pastor, F. I. J. - Purification and properties of xylanase A from alkali-tolerant Bacillus sp strain BP-23. Appl. Env. Microbiol. 61: 4468-4470, 1995.

6. Daneault, C.; Leduc, C.; Valade, J. L. - The use of xylanases in kraft pulp bleaching: a review. Tappi J. 77: 125-131, 1994.

7. Duarte, M. C. T.; Portugal, E. P.; Ponezi, A. N.; Franco, T. T. - Otimização da produção de xilanases alcalinas por diferentes cepas de Bacillus pumilus. Anais do XII SINAFERM - Simpósio Nacional de Fermentações, UFSCAR, Brazil, 1998, MSC-F3.

8. Duarte, M. C. T.; Portugal, E. P.; Ponezi, A. N.; Franco T. T. - Alkalophilic xylanases production from bacteria. Proc. 5th Brazilian Symposium on the Chemistry of Lignins and Other Wood Components, UFPR Curitiba, Brazil, 1997, p. 340-345.

9. Duarte, M. C. T.; Portugal, E. P.; Ponezi, A. N.; Bim, M. A.; Tagliari, C. V.; Franco, T. T. - Production and purification of alkaline xylanases by partitioning in aqueous two-phase systems. Biores. Technol. 66: 49-53, 1998.

10. Ghose, T. K. - Measurement of cellulase activities. Pure Appl. Chem. 59: 257-268, 1987

11. Lineweaver, H.; Burk, D. - The determination of enzyme dissociation constants. J. Am. Chem. Soc. 56: 658-666, 1934.

12. Mandels, M.; Stenberg, D. - Recent advances in cellulase technology. $J$. Ferment. Technol.; 54: 267-286, 1976.

13. Miller, G. L. - Use of dinitrosalicylic acid reagent for determination of reducing sugar. Anal. Chem. 31: 426-428,1959.

14. Morales, P.; Madarro, A.; Flors, A.; Sendra, J. M.; Pérez-Gonzáles, J. A. Purification and characterization of a xylanase and an arabinofuranosidade from Bacillus polymyxa. Enz. Microbial Technol. 17: 424-429, 1995.

15. Paice, M. G.; Gurnagul, N.; Page, D. H.; Jurasek, L. - Mechanisms of hemicellulose-directed prebleaching of kraft pulps. Enz. Microb. Technol. 14: 272-276, 1992

16. Sedmak, J. J.; Grossberg, S. E. - A rapid, sensitive, and versatile assay for protein using Coomasie Brilliant Blue F-250. Analytical Biochem. 79: 544-552, 1977.

17. Shao, W.; Schwartz, Z.; Khasin, A.; Gat, O.; Zosim, Z.; Rosenberg, E. Delignification of wood pulp by a thermostable xylanase from Bacillus stearothermophilus T-6. Biodegradation, 3: 207-218, 1992.

18. Shoham, Y.; Schwartz, Z.; Khashin, A.; Gat, O.; Zosim, Z.; Rosenberg, E. - Delignification of wood pulp by a thermostable xylanase from Bacillus stearothermophilus T-6. Biodegradation. 3: 207-218, 1992.

19. Tremblay, L.; Archibald, F. - Production of a cloned xylanase in Bacillus cereus and its performance in kraft pulp prebleaching. Can. J. Microbiol. 39: 853-860, 1993.

20. Viikari, L.; Kantelinen, A.; Sundquistand, J.; Linko, M. - Xylanases in bleaching: from an idea to the industry. FEMS Microbiol. 13: 335-350, 1994 .

21. Viikari, L.; Ranua, M.; Kantelinen, A.; Sundquistand, J.; Linko, M. Bleaching with enzymes. Proc. Third Int. Conf. Biotechnol. Pulp Paper Industry, Stockholm, 1986, p. 67-69.

22. Yang, J. L.; Lou, G.; Eriksson, K. L. - The impact of xylanase on bleaching of kraft pulp. Tappi J. 75: 95-101, 1992.

23. Yang, V. W.; Zhuang, Z.; Elegir, G.; Jeffries, T. W. - Alkaline-active xylanase produced by an alkaliphilic Bacillus sp isolated from kraft pulp. J. of Ind. Microbiol. 15: 434-441, 1995. 